\title{
PENGEMBANGAN PERANGKAT PEMBELAJARAN KESEBANGUNAN BANGUN DATAR BERBASIS TEORI VAN HIELE UNTUK MENINGKATKAN KEMAMPUAN BERPIKIR TINGKAT TINGGI SISWA
}

\author{
Aidatul Masrurroh \\ Program Studi Pendidikan Matematika, Jurusan Matematika, FMIPA, Universitas Negeri Surabaya \\ e-mail: aidatulmasrurroh16030174083@mhs.unesa.ac.id \\ Masriyah \\ Program Studi Pendidikan Matematika, Jurusan Matematika, FMIPA, Universitas Negeri Surabaya \\ $e$-mail: masriyah@unesa.ac.id
}

\begin{abstract}
Abstrak
Dalam mengimplementasikan kurikulum 2013, kemampuan berpikir tingkat tinggi harus diintegrasikan ke pembelajaran. Kesebangunan adalah sub materi dari kesebangunan dan kekongruenan yang harus dipelajari siswa. Pada kenyataannya kemampuan berpikir tingkat tinggi siswa SMP pada materi kesebangunan termasuk rendah. Untuk mengatasi hal tersebut perlu dikembangkan perangkat pembelajaran terhadap pembelajaran kesebangunan bangun datar yang sesuai dengan tingkat berpikir siswa dalam geometri, yaitu berbasis teori Van Hiele untuk meningkatkan kemampuan berpikir tingkat tinggi siswa. Teori Van Hiele dipilih karena mengemukakan tentang perkembangan berpikir siswa dalam pembelajaran geometri terjadi melalui lima tingkatan (atau levels) secara berurutan sehingga perangkat pembelajaran dapat dikembangkan sesuai dengan level van Hiele siswa. Tujuan penelitian ini adalah memperoleh deskripsi proses dan menghasilkan perangkat pembelajaran kesebangunan bangun datar berbasis teori van Hiele untuk meningkatkan kemampuan berpikir tingkat tinggi siswa yang valid, praktis, dan efektif. Jenis penelitian ini adalah penelitian pengembangan dengan menggunakan model 4-D yang dikemukakan oleh Thiagarajan kemudian dilakukan penyederhanaan menjadi model 3-D.Validasi perangkat pembelajaran, observasi partisipan, angket, dan tes merupakan Teknik pengumpulan data yang digunakan. Hasil penelitian menunjukkan bahwa RPP, LKS, dan THB dikatakan valid maka, perangkat pembelajaran dinyatakan valid; pengelolaan pembelajaran dikatakan baik, penilaian secara umum pada lembar validasi perangkat pembelajaran dinyatakan dapat digunakan, dan persentase aktivitas siswa aktif pada pertemuan kedua dan pertemuan ketiga masing-masing sebesar $91,25 \%$ dan $91,25 \%$ maka, perangkat pembelajaran dinyatakan praktis; dan persentase respon positif siswa sebesar $71 \%$ dan peningkatan kemampuan berpikir tingkat tinggi dilihat dari hasil $\mathrm{N}$-Gain pretest dan posttest sebesar 0,728 berkategori tinggi maka, perangkat pembelajaran dinyatakan efektif.
\end{abstract}

Kata Kunci: perangkat pembelajaran, kesebangunan bangun datar, teori van hiele, kemampuan berpikir tingkat tinggi.

In implementing the 2013 curriculum, Higher Order Thinking Skills (HOTS) must be integrated into learning activities. Similarity are sub material of similarity and congruence that students must learn. In fact, the higher order thinking skills of junior high school students in similarity material is low. To overcome this problem, it is necessary to develop a learning materials for learning in the form of plane similarity according to the level of student thinking in geometry, which is based on Van Hiele's theory to improve students' higherorder thinking skills. Van Hiele's theory was chosen because it suggests the development of students' thinking in learning of geometry occurs through five levels sequentially so that learning devices can be developed according to the level of van Hiele students. The purpose of this research is to obtain a description of the learning materials of plane similarity based on van Hiele theory based on van Hiele theory to improve students' high-level thinking skills that are valid, practical, and effective. This type of research is a research development using the 4-D model proposed by Thiagarajan then simplified to a 3-D model. Validation of learning devices, participant observation, questionnaires, and tests are the data collection techniques used.

The results showed that the RPP, LKS, and THB were said to be valid then, the learning materials was declared valid; the management of learning is said to be good, the overall evaluation on the validation sheet of the learning materials is stated to be used, and the percentage of active student activities at the second meeting and the third meeting respectively is $91.25 \%$ and $91.25 \%$ then, the learning kit is declared practical; and the percentage of positive responses of students by $71 \%$ and an increase in higher order thinking skills 
seen from the results of the N-Gain pretest and posttest of 0,728 categorized as high then, the learning device is declared effective.

Keywords: learning materials, plane similarity, van hiele's theory, higher order thinking skills.

\section{PENDAHULUAN}

Matematika adalah aspek yang penting dalam kehidupan terutama dalam pendidikan. Peluang, aljabar, geometri dan pengukuran; statistika, dan bilangan merupakan materi dalam matematika yang diajarkan pada jenjang SMP/MTs (Kemendikbud, 2017). Pada jenjang SMP/MTs perbandingan antara Geometri dan Pengukuran, Statistika dan Peluang, Aljabar, dan Bilangan masingmasing berturut-turut adalah $39 \%, 6 \%, 39 \%$, dan $16 \%$ bila dipandang dari KD mata pelajaran matematika (Rosnawati, 2013:2). Hal ini menunjukkan bahwa geometri adalah salah satu dari ruang lingkup matematika yang mendominasi. Pada kenyataannya pembelajaran geometri dalam pengamatan peneliti termasuk sulit menurut siswa. Artinya, dalam memahami geometri siswa merasakan kesulitan. Hal ini sesuai dengan daya serap matematika pada Ujian Nasional Tahun 2018/2019 dalam Puspendik (2019) menyatakan bahwa materi geometri dan pengukuran, statistika dan peluang, aljabar, dan bilangan masingmasing berturut-turut memperoleh $42,27 \%$, 55,60\%, $51,24 \%$, dan $39,71 \%$. Hal tersebut menunjukkan bahwa penguasaan materi siswa pada materi geometri dan pengukuran masih di bawah penguasaan materi pada materi aljabar dan statistika dan peluang. Salah satu aspek geometri dan pengukuran, yaitu kesebangunan bangun datar. Kesesuaian dua bangun datar dengan perbandingan sisi-sisi yang bersesuaian sama besar dan sudut-sudut yang bersesuaian sama besar adalah kesebangunan bangun datar.

Puspendik (2019) menyatakan sub materi kesebangunan termasuk ke dalam indikator yang diuji dalam UN SMP/MTs tahun pelajaran 2018/2019 dengan nilai daya serap 45,39 atau kurang dari 55 yang ditetapkan. Artinya, kemampuan siswa pada sub materi kesebangunan termasuk rendah karena nilai daya serap yang diperoleh siswa berada di bawah rata-rata yang ditetapkan oleh pemerintah. Siswa mengalami kesulitan dalam pembelajaran kesebangunan. Salah satu cara untuk mengatasi kesulitan siswa tersebut harus dilakukan suatu pengembangan perangkat pembelajaran terhadap pembelajaran.

Abdussakir (2009) menyatakan bahwa dalam pembelajaran geometri, ketidakmampuan siswa dapat diatasi dengan menggunakan teori perkembangan Van Hiele. Guru harus menyediakan sebuah perangkat pembelajaran yang disesuaikan dengan kemampuan geometri siswa sehingga pembelajaran berjalan sesuai dengan tujuan pembelajaran. Teori Van Hiele adalah teori yang menerangkan bahwa dalam pembelajaran geometri siswa mengalami lima levels secara berurutan. Guru dapat mengembangkan sebuah perangkat pembelajaran yang sesuai level van Hiele siswa dan dapat mengajarkan materi geometri dengan cara mengikuti urutan tahap belajar dari Van Hiele.

Menurut Vojkuvkova (2012), Lima levels Van Hiele, yaitu:

(1) Level 0 (Visualisasi)

Tidak selalu melalukan pengidentifikasian sifat bangun secara spesifik dan pemberian nama dan pengenalan bentuk bangun gometri oleh siswa.

(2) Level 1 (Analisis)

Hubungan antar sifat tidak semua dapat dijelaskan, pemahaman definisi belum ada, dan pendeskripsian sifat bentuk bangun geometri oleh siswa.

(3) Level 2 (Deduksi Informal)

Pengklasifikasian bangun secara hirarki, deduksi informal digunakan untuk menemukan sifat bangun, pembuatan definisi abstrak, hubungan antar sifat bentuk bangun geometri dapat dijelaskan oleh siswa.

(4) Level 3 (Deduksi)

Bukti bahkan lebih dari satu cara dan teorema dalam sistem aksiomatik dapat disusun oleh siswa.

(5) Level 4 (Rigor)

Penelaah berbagai geometri tanpa model konkret dan sistem geometris atau aksioma yang berbeda dapat dibandingkan oleh siswa.

Menurut Sunardi (2005), Lima tahap-tahap belajar geometri menurut teori Van Hiele yang diintegrasikan ke dalam model pembelajaran yang digunakan pada RPP, yaitu:

(1) Tahap 1 Informasi

Pengidentifikasian pengetahuan sebelumnya yang berkaitan dengan yang akan diajarkan sehingga dapat menghubungkan dengan materi tersebut yang dilakukan oleh guru.

(2) Tahap 2 Orientasi terarah

Pengeksplorasi objek geometri melalui LKS secara aktif seperti pengkonstruksian, pengukuran, dan pelipatan.

(3) Tahap 3 Eksplisitasi

Penggambaran materi yang telah dipelajari dengan bahasa siswa sendiri.

(4) Tahap 4 Orientasi bebas

Penerapan hubungan atau pengetahuan geometri yang sedang dipelajari untuk menyelesaikan soal terbuka.

(5) Tahap 5 Integrasi

Rangkuman dari yang telah dipelajari dengan cara menghubung-hubungkan dilakukan oleh siswa. 
Dalam mengimplementasi kurikulum 2013, salah satu unsur yang harus diintegrasikan ke perangkat pembelajaran, yaitu Kemampuan berpikir tingkat tinggi (Prasetyo, dkk, 2019). Guru dituntut untuk menyajikan pembelajaran dengan berbasis kemampuan berpikir tingkat tinggi yang meliputi berpikir kreatif, dan berpikir kritis.

Kategori kemampuan berpikir tingkat tinggi menurut Krathwohl (2002) terdiri atas:

a. Menganalisis (Analyze)/ $\mathrm{C}_{4}$ : Keseluruhan struktur atau tujuan dihubungkan dengan bagian-bagian yang berasal dari pemecahan penyusun materi.

b. Mengevaluasi (Evaluate)/ $\mathrm{C}_{5}$ : Kriteria dan standar dibuat dalam pembuatan penilaian.

c. Mencipta (Create)/ $\mathrm{C}_{6}$ : Pembentukan atau pembuatan sesuatu yang baru atau asli dari penyatuan bagianbagian.

Siswa dituntut untuk melatih kemampuan berpikir tingkat tinggi untuk memecahkan masalah. Masriyah, et al. (2018) menyatakan bahwa guru pre-service perlu terbiasa untuk membuat masalah yang terbuka untuk masa depan siswa. Artinya, guru harus membuat soal dengan berbagai tingkatan, yaitu kemampuan berpikir tingkat rendah (mengingat, memahami, dan mengaplikasikan) dan kemampuan berpikir tingkat tinggi (menganalisis, mengevaluasi, dan mencipta) agar kemampuan berpikir siswa pada masa depan menjadi lebih baik. Guru harus mengintegrasikan kemampuan berpikir tingkat tinggi ke dalam perangkat pembelajaran. Sedangkan, Siregar (2016) menyimpulkan bahwa kesulitan siswa di SMP YPK Medan, MTs.N 1 Medan, dan SMP Darul Aman Medan alam mengerjakan soal kesebangunan ditinjau dari Taksonomi Bloom masing-masing berturut-turut menganalisis mencapai 46,58\%, 56,26\%, 57,54\%; mensistensis mencapai $51,25 \%, 45 \%, 50,14 \%$; dan mengevaluasi mencapai 50,16\%, 55,32\%, 58,48\%. Dapat disimpulkan bahwa siswa mengalami kesulitan dalam pembelajaran kesebangunan bangun datar karena hasil yang diperoleh di bawah $60 \%$. Dari hasil beberapa penelitian tersebut, dapat disimpulkan bahwa kemampuan berpikir tingkat tinggi siswa SMP pada materi kesebangunan termasuk rendah.

Penyebab ketidakmampuan siswa Indonesia pada kemampuan berpikir tingkat tinggi dinyatakan oleh Kasturi, dkk (2015), penyebab ketidakmampuan kemampuan berpikir tingkat tinggi siswa dalam kesebangunan karena guru tidak mengintegrasikan kemampuan berpikir tingkat tinggi ke dalam pembelajaran. Pembelajaran harus dirancang sesuai dengan tingkat berpikir siswa, maka dikembangkan sebuah perangkat pembelajaran sesuai dengan kemampuan siswa dalam geometri secara berurutan sesuai dengan level Van Hiele siswa dengan mengintegrasikan tahap-tahap pembelajaran Van Hiele dalam pembelajaran. Teori van Hiele dipilih karena mengemukakan level berpikir siswa dalam geometri secara berurutan sehingga perangkat pembelajaran dapat dikembangkan sesuai dengan kemampuan berpikir geometri siswa. Perangkat pembelajaran antara lain terdiri dari tes hasil belajar (THB), lembar kerja siswa (LKS), dan rencana pelaksanaan pembelajaran (RPP).

Berdasarkan uraian di atas, maka judul dari penelitian ini adalah Pengembangan perangkat pembelajaran geometri berbasis teori Van Hiele untuk meningkatkan kemampuan berpikir tingkat tinggi siswa.

Tujuan penelitian ini adalah memperoleh deskripsi proses dan menghasilkan perangkat pembelajaran kesebangunan bangun datar berbasis teori van Hiele untuk meningkatkan kemampuan berpikir tingkat tinggi siswa yang valid, praktis, dan efektif.

Penelitian relevan adalah penelitian Puspitasari (2013) yang menghasilkan keefektifan dari pengembangan perangkat pembelajaran berbasis teori van Hiele dan Sunardi (2005) yang mengatakan bahwa model PBH yang dikembangkan memenuhi kriteria valid, praktis, dan efektif.

\section{METODE}

Penelitian pengembangan merupakan jenis dari penelitian ini yang mengembangkan perangkat pembelajaran berupa LKS, RPP, dan THB dengan menggunakan model 4-D yang dikemukakan oleh Thiagarajan, et al (1974) kemudian dilakukan penyederhanaan menjadi model 3-D untuk menyesuaikan dengan tujuan penelitian ini yang meliputi: (1) tahap pendefinisian: Analisis awal akhir, analisis siswa, analisis konsep, analisis tugas, dan spesifikasi tujuan pembelajaran. (2) tahap perancangan:, penyusunan tes, pemilihan format, dan perancangan awal. (3) tahap pengembangan: penilaian ahli, uji pengembangan, dan analisis data uji coba.

Perangkat pembelajaran dinyatakan valid jika kriteria kevalidan RPP, LKS, dan THB minimal tergolong valid.

Perangkat pembelajaran dinyatakan praktis jika kriteria berikut terpenuhi.. (1) Pengelolaan pembelajaran memenuhi kategori minimal baik. (2) Hasil penilaian secara umum pada lembar validasi perangkat pembelajaran minimal memenuhi kategori dapat digunakan. (3) Aktivitas siswa minimal memenuhi kategori aktif.

Perangkat pembelajaran dapat dinyatakan efektif jika kriteria berikut terpenuhi. (1) N-Gain peningkatan kemampuan berpikir tingkat tinggi minimal memenuhi kategori sedang. (2) Respon siswa minimal memenuhi kategori positif.

Satu kelas siswa kelas IX SMP Negeri 2 Krian tahun pelajaran 2019-2020, yaitu kelas IX F merupakan subjek uji coba penelitian ini.

Instrumen pengumpulan data yang digunakan dalam penelitian ini sebagai berikut. (1) Lembar Tes Level 
Kemampuan Berpikir Siswa dalam Geometri: Instrumen ini mengadopsi dari Sunardi (2000) dan digunakan untuk memperoleh data level van Hiele siswa untuk dijadikan dasar pengembangan perangkat pembelajaran. (2) Lembar Validasi Perangkat Pembelajaran: untuk memperoleh data validasi oleh validator terhadap perangkat pembelajaran serta kritik dan saran terhadap perangkat pembelajaran berupa LKS, RPP, dan THB. (3) Lembar Observasi Pengelolaan Pembelajaran: untuk memperoleh data kemampuan guru dalam mengelola pembelajaraan oleh observer. (4) Lembar Observasi Aktivitas Siswa: untuk memperoleh data aktivitas siswa selama pembelajaran menggunakan perangkat pembelajaran yang telah dikembangkan. (5) Angket Respon Siswa: untuk memperoleh data mengenai keefektifan pembelajaran menggunakan perangkat pembelajaran. (6) Tes Hasil Belajar (THB): untuk memperoleh data nilai dari setiap siswa terhadap THB yang mengacu pada kemampuan berpikir tingkat tinggi guna melihat peningkatan dari pretest dan posttest.

Berdasarkan instrumen pengumpulan data yang dirancang kemudian menganalisis data dengan teknik analisis data sebagai berikut. (1) Analisis Tes Level Kemampuan Berpikir Siswa dalam Geometri: Menurut Yudianto (2011), Minimal tiga dari lima soal level ke $n$ dijawab benar dan setiap level sebelumnya maka siswa dapat diklasifikasikan ke dalam level ke n. Siswa diklasifikasikan ke dalam level pravisualisasi jika siswa tidak memenuhi kriteria sebelumnya. (2) Analisis Lembar Validasi Perangkat Pembelajaran: Modus semua aspek $(V)$ dari masing-masing perangkat pembelajaran dicocokkan dengan kriteria kevalidan menurut Masriyah (2018) berikut ini. $V=5$ Sangat Valid, $V=4$ Valid, $V=3$ Cukup Valid, $V=2 \quad$ Kurang Valid, dan $V=1$ Sangat Kurang Valid. (3) Analisis Lembar Observasi Pengelolaan Pembelajaran: Modus semua aspek $\left(K_{P P}\right)$ dicocokkan dengan kriteria kepraktisan menurut Masriyah (2018) berikut ini. $K_{P P}=5$ Sangat Baik, $K_{P P}=4$, Baik, $K_{P P}=3$ Cukup Baik, $K_{P P}=2$ Kurang Baik, $K_{P P}=1$ Sangat Kurang Baik. (4) Analisis Lembar Observasi Aktivitas Siswa: Persentase frekuensi masing-masing aktivitas siswa pada setiap pertemuan pembelajaran dihitung. (5) Analisis Angket Respon Siswa: Menghitung persentase jumlah jawaban "Ya" kemudian dicocokkan dengan interval kriteria respon siswa dari Yamasari (2010). (6) Analisis Tes Hasil Belajar (THB): Menghitung nilai setiap siswa sehingga dapat dihitung skor $\mathrm{N}$-Gain peningkatan kemampuan berpikir tingkat tinggi siswa. Kemudian dicocokkan dengan kategori N-Gain dari Hake (1999)

\section{HASIL DAN PEMBAHASAN}

Penelitian ini menggunakan model penelitian pengembangan penyederhanaan 3-D oleh Thiagarajan, et al
(1974). Hasil dari setiap tahap-tahap dalam penelitian ini dijelaskan sebagai berikut.

(1) Tahap Pendefinisian

a. Analisis awal-akhir

Masalah saat KBM adalah perangkat pembelajaran tidak sesuai dengan kemampuan berpikir siswa dalam geometri, soal kesebangunan yang dikembangkan tidak termasuk ke dalam soal HOTS, dan kemampuan berpikir tingkat tinggi siswa dalam materi kesebangunan bangun datar termasuk rendah.

b. Analisis siswa

Klasifikasi level van Hiele pada kelas IX F di SMP Negeri 2 Krian meliputi level Pravisualisasi sebanyak 6 siswa, level 0 sebanyak 17 siswa, dan level 1 sebanyak 10 siswa sehingga RPP dan LKS disusun berdasarkan level 0 dan level 1 .

c. Analisi konsep

Konsep utama yang akan dipelajari adalah kesebangunan bangun datar di kelas IX SMP yang mengacu pada kurikulum 2013.

d. Analisis tugas

Tugas-tugas siswa adalah menemukan syaratsyarat bangun datar dikatakan sebangun, menguji dua bangun datar sebangun atau tidak, dan menyelesaikan masalah terkait kesebangunan bangun datar.

e. Spesifikasi tujuan pembelajaran

Tujuan pembelajaran menginstruksikan siswa untuk dapat mencapai tugas-tugas yang diberikan.

(2) Tahap Perancangan

a. Penyusunan tes

Tes yang disusun berupa Tes Hasil Belajar (THB)

berbasis soal HOTS.

b. Pemilihan format

LKS, RPP, dan THB disusun berdasarkan formatformat yang ada pada Kajian Pustaka.

Perancangan awal

Perancangan perangkat pembelajaran berupa RPP dan LKS disusun berdasarkan tahap pendefinisian, serta THB disusun berdasarkan kemampuan berpikir tingkat tinggi dalam bentuk Draft I. Sedangkan instrumen penelitian yang dirancang meliputi: lembar observasi pengelolaan pembelajaran, lembar validasi perangkat pembelajaran, angket respon siswa, lembar aktivitas siswa, dan THB.

(3) Tahap Pengembangan

a. Penilaian ahli

Penilaian pada RPP, LKS, dan THB masingmasing memperoleh modus semua aspek sebesar 4, jadi dengan berdasar pada kriteria Masriyah (2018) maka dapat dinyatakan valid. Selain itu 
penilaian umum dinyatakan oleh validator bahwa RPP, LKS, dan THB dapat digunakan dengan revisi sesuai kritik dan saran. Kemudian direvisi oleh peneliti supaya RPP, LKS, dan THB dapat digunakan tanpa revisi.

b. Uji Pengembangan

RPP, LKS, dan THB diujicobakan di satu kelas, yaitu kelas IX F di SMP Negeri 2 Krian, Sidoarjo. Uji coba perangkat pembelajaran dilakukan sebanyak 4 (empat) kali pertemuan dengan masing-masing 2 kali pertemuan pembelajaran dan THB.

c. Analisis data uji coba

Hasil observasi pengelolaan pembelajaran dalam 2 (dua) kali pertemuan diperoleh modus semua aspek adalah 4, jadi dengan berdasar pada kriteria menurut Masriyah (2018) maka pengelolaan pembelajaran dapat dinyatakan baik.

Hasil observasi aktivitas siswa dalam 2 kali pertemuan diperoleh jumlah persentase semua aktivitas kecuali aspek "Melakukan aktivitas yang tidak relevan dengan KBM", yaitu pada pertemuan kedua diperoleh 91,25\% dan pertemuan ketiga diperoleh $91,25 \%$. Berdasar dari perolehan tersebut maka dapat dinyatakan aktif karena hasil aktivitas siswa kecuali aspek "Melakukan aktivitas yang tidak relevan dengan

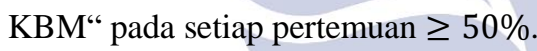

Hasil angket respon positif siswa terhadap perangkat pembelajaran diperoleh persentase jawaban "Ya" adalah 71\% dari 35 siswa yang mengisi lembar angket respon siswa, jadi dengan berdasar pada kriteria Yamasari (2010) maka dapat dinyatakan positif.

Hasil uji N-Gain setiap siswa terdiri dari kategori tinggi, sedang, dan rendah masingmasing sejumlah 25 siswa, 10 siswa, dan 0 siswa berdasarkan Hake (1999).

Skor N-Gain pada setiap kategori kemampuan berpikir tingkat tinggi meliputi kategori menganalisis sebesar 0,779 termasuk kategori tinggi, kategori mengevaluasi sebesar 0,777 termasuk kategori tinggi, dan kategori mencipta sebesar 0,640 termasuk kategori sedang.

Hasil analisis uji N-Gain secara keseluruhan dari nilai rata-rata pretest dan posttest diperoleh nilai N-Gain sebesar 0,728 termasuk kategori tinggi.

Berdasarkan hasil yang telah dipaparkan maka, dapat dijelaskan pembahasannya berikut ini.

(1) Proses pengembangan perangkat pembelajaran kesebangunan bangun datar berbasis teori Van Hiele untuk meningkatkan kemampuan berpikir tingkat tinggi siswa

RPP, LKS, dan THB adalah hasil dari pengembangan perangkat pembelajaran kesebangunan bangun datar berbasis teori Van Hiele untuk meningkatkan kemampuan berpikir tingkat tinggi siswa. Sebelum dilakukan pengembangan perangkat pembelajaran, dilakukan analisis terlebih dahulu pada masalah guru yang sedang dihadapi pada saat kegiatan belajar mengajar. Masalah tersebut adalah ketidakmampuan siswa dalam materi kesebangunan terkait menggunakan kemampuan berpikir tingkat tinggi maka, perlu dilakukan pengembangan perangkat pembelajaran kesebangunan bangun datar berbasis teori van Hiele untuk meningkatkan kemampuan berpikir tingkat tinggi siswa. Kemudian untuk mengembangkan perangkat pembelajaran berbasis teori van Hiele maka, diberikan tes level kemampuan berpikir siswa dalam geometri pada satu kelas IX F di SMP Negeri 2 Krian guna untuk mengecek level van Hiele setiap siswa dalam satu kelas tersebut. Berdasarkan hasil tes tersebut diperoleh level van Hiele setiap siswa dalam kelas tersebut, yaitu level pravisualisasi sebanyak 6 siswa, level 0 sebanyak 17 siswa, dan level 1 sebanyak 10 siswa. Dari hasil tersebut maka perangkat pembelajaran berbasis teori van Hiele dapat dikembangkan dengan berdasar pada aktivitas siswa pada level 0 sampai level 1 .

Materi yang digunakan adalah kesebangunan bangun datar atau sub bab dari bab kesebangunan dan kekongruenan. RPP dikembangkan berdasarkan tahap-tahap belajar teori van Hiele serta aktivitas siswa disusun berdasarkan level 0 sampai level 1. RPP terdiri dari 4 kali pertemuan, yaitu dengan tes sebanyak 2 kali pertemuan dan kegiatan belajar mengajar sebanyak 2 kali pertemuan. Pertemuan pertama dilakukan pretest, pertemuan kedua dilakukan kegiatan belajar mengajar, pertemuan ketiga dilakukan kegiatan belajar mengajar, dan pertemuan keempat dilakukan posttest. Setelah pengembangan RPP, dikembangkan LKS berdasarkan RPP guna untuk menunjang pembelajaran dalam mencapai tujuan pembelajaran pada RPP dan kurikulum 2013 dengan mengimplementasikan soal HOTS dalam LKS. LKS terdiri dari LKS I (Kegiatan I dan Kegiatan II) dan LKS II (Kegiatan I dan Kegiatan II). LKS I dan LKS II masing-masing digunakan pada pertemuan ke 2 dan ke 3.

Pengembangan yang ketiga yaitu dilakukan pengembangan THB. THB disusun berdasarkan HOTS guna untuk mengetahui peningkatan HOTS siswa setelah diterapkan perangkat pembelajaran berbasis teori van Hiele. THB terdiri dari 3 soal uraian. Dimensi proses kognitif soal nomor 1 adalah 
menganalisis. Dimensi proses kognitif soal nomor 2 adalah mengevaluasi. Dimensi proses kognitif soal nomor 3 adalah mencipta.

Setelah perancangan awal selesai, validator melakukan validasi untuk memperoleh perangkat pembelajaran yang valid. Kemudian, kerpraktisan dan keefektifan dilihat dari uji coba perangkat pembelajaran. Hasil pengamatan pengelolaan pembelajaran dan aktivitas siswa yang dilakukan observer dan hasil validasi perangkat pembelajaran apakah dapat digunakan atau tidak dapat digunakan untuk menyatakan kepraktisan. Keefektifan dilihat dari hasil respon siswa yang diisi siswa setelah dilaksanakan THB posttest dan hasil peningkatan THB yang dianalisis dengan menggunakan N-Gain. Jadi, setelah melalui proses yang telah diuraikan maka didapatkan perangkat pembelajaran kesebangunan bangun datar berbasis teori van Hiele yang valid, praktis, dan efektif.

(2) Hasil pengembangan perangkat pembelajaran kesebangunan bangun datar berbasis teori Van Hiele untuk meningkatkan kemampuan berpikir tingkat tinggi siswa

a. Validasi RPP, LKS, dan THB

Penilaian pada RPP, LKS, dan THB masingmasing memperoleh modus semua aspek sebesar 4, jadi dengan berdasar pada kriteria Masriyah (2018) maka dapat dinyatakan valid. Selain itu penilaian umum dinyatakan oleh validator bahwa RPP, LKS, dan THB dapat digunakan dengan revisi sesuai kritik dan saran. Kemudian direvisi oleh peneliti supaya RPP, LKS, dan THB dapat digunakan tanpa revisi. Hasil tersebut sesuai dengan hasil penelitian Sunardi (2005) yang menunjukkan perangkat pembelajaran berbasis teori van Hiele berupa RP, LKS, Paket Kuis dan Paket Tes Penguasaan Bahan Pembelajaran yang dikembangkan dapat dinyatakan valid.

Dari hasil tersebut, maka perangkat pembelajaran dapat dinyatakan valid.

b. Pengelolaan Pembelajaran

Hasil observasi pengelolaan pembelajaran dalam 2 (dua) kali pertemuan diperoleh modus semua aspek adalah 4, jadi dengan berdasar pada kriteria menurut Masriyah (2018) maka pengelolaan pembelajaran dapat dinyatakan baik. Hasil tersebut sesuai dengan hasil penelitian Kamaruddin, dkk (2014) yang menunjukkan bahwa pengelolaan pembelajaran berbasis teori van Hiele oleh guru termasuk dalam kriteria baik.

c. Aktivitas siswa dalam pembelajaran

Hasil observasi aktivitas siswa dalam 2 kali pertemuan diperoleh jumlah persentase semua aktivitas kecuali aspek "Melakukan aktivitas yang tidak relevan dengan KBM", yaitu pada pertemuan kedua diperoleh $91,25 \%$ dan pertemuan ketiga diperoleh $91,25 \%$. Berdasar dari perolehan tersebut maka dapat dinyatakan aktif karena hasil aktivitas siswa kecuali aspek "Melakukan aktivitas yang tidak relevan dengan KBM" pada setiap pertemuan $\geq 50 \%$. Hasill tersebut selaras dengan hasil penelitian Nurdin (2016) yang menunjukkan bahwa aktivitas siswa dalam pembelajaran yang mengintegrasikan teori van Hiele memenuhi kriteria Baik.

d. Respon Siswa

Hasil angket respon positif siswa terhadap perangkat pembelajaran diperoleh persentase jawaban "Ya" adalah 71\% dari 35 siswa yang mengisi lembar angket respon siswa, jadi dengan berdasar pada kriteria Yamasari (2010) maka dapat dinyatakan positif. Hasil tersebut sesuai dengan hasil penelitian Nurdin (2016) bahwa respon siswa dalam pembelajaran yang mengintegrasikan teori van Hiele memenuhi kriteria Cenderung Positif.

e. Peningkatan kemampuan berpikir tingkat tinggi siswa

Hasil uji N-Gain setiap siswa, yaitu $71 \%$ berkategori tinggi, $29 \%$ berkategori sedang, dan $0 \%$ berkategori rendah. Dari hasil tersebut dapat diketahui bahwa persentase tertinggi adalah kategori tinggi. Artinya, peningkatan terjadi secara signifikan pada hasil THB pretest ke THB posttest siswa. Artinya, perangkat pembelajaran kesebangunan bangun datar berbasis teori van Hiele dalam meningkatkan kemampuan berpikir tingkat tinggi siswa tinggi.

Skor N-Gain pada setiap kategori kemampuan berpikir tingkat tinggi meliputi kategori menganalisis sebesar 0,779 termasuk kategori tinggi, kategori mengevaluasi sebesar 0,777 termasuk kategori tinggi, dan kategori mencipta sebesar 0,640 termasuk kategori sedang. Pada perolehan skor N-Gain urutan terbesar ke terkecil masing-masing berturut-turut kategori menganalisis, mengevaluasi, dan mencipta. Hal tersebut sesuai dengan Krathwohl (2002) yang menjelaskan bahwa kategori kemampuan berpikir tingkat tinggi meliputi menganalisis, mengevaluasi, dan mencipta yang tingkat kesulitannya berurutan dari menganalisis lebih mudah dibanding mengevaluasi dan mengevaluasi lebih mudah dibanding mencipta.

Hasil analisis uji N-Gain secara keseluruhan dari nilai rata-rata pretest dan posttest diperoleh 
nilai $\mathrm{N}$-Gain sebesar 0,728 termasuk kategori tinggi. Hasil tersebut sesuai dengan hasil penelitian Nurdin (2016) yang menunjukkan bahwa efektivitas pembelajaran ICARE terintegrasi teori van Hiele memperoleh N-Gain berkriteria tinggi.

Dari hasil penelitian lain yang telah diuraikan dapat disimpulkan bahwa hasil N-Gain yang termasuk berkategori tinggi disebabkan karena pembelajaran berbasis teori van Hiele sehingga dapat meningkatkan kemampuan siswa, yaitu dalam hal ini kemampuan berpikir tingkat tinggi.

Kriteria pengelolaan pembelajaran termasuk baik, penilaian secara umum pada lembar validasi perangkat pembelajaran dinyatakan dapat digunakan, dan persentase aktivitas siswa aktif pada pertemuan kedua dan pertemuan ketiga masing-masing sebesar 91,25\% dan 91,25\%. Jadi, perangkat pembelajaran dapat dinyatakan praktis.

Respon positif siswa sebesar $71 \%$ dan dan N-Gain setiap siswa, yaitu $71 \%$ berkategori tinggi, $29 \%$ berkategori sedang, dan 0\% berkategori rendah. Dari hasil tersebut maka, perangkat pembelajaran kesebangunan bangun datar berbasis teori van Hiele dapat meningkatkan kemampuan berpikir tingkat tinggi siswa. N-Gain setiap kategori HOTS siswa, yaitu kategori menganalisis sebesar 0,779 berkategori tinggi, kategori mengevaluasi sebesar 0,777 berkategori tinggi, dan kategori mencipta sebesar 0,640 berkategori sedang. N-Gain secara keseluruhan dari skor rata-rata pretest dan posttest sebesar 0,728 berkategori tinggi. Jadi, perangkat pembelajaran dapat dinyatakan efektif.

Berdasarkan uraian di atas, perangkat pembelajaran memenuhi kriteria valid, praktis, dan efektif. Hasil tersebut sesuai dengan penelitian Sunardi (2005) yang mengatakan bahwa model PBH yang dikembangkan memenuhi kriteria valid, praktis, dan efektif.

\section{PENUTUP}

\section{Simpulan dan Saran}

Simpulan dari penelitian ini dipaparkan sebagai berikut.

(1) Proses pengembangan perangkat pembelajaran kesebangunan bangun datar berbasis teori van Hiele untuk meningkatkan kemampuan berpikir tingkat tinggi siswa diuraikan sebagai berikut:

Tahap awal yang dilaksanakan adalah tahap pendefinisian. Tahap pendefinisian terdiri dari beberapa analisis, yaitu a) Analisis awal-akhir perangkat: pembelajaran tidak sesuai dengan kemampuan berpikir siswa dalam geometri dan HOTS siswa dalam materi kesebangunan bangun datar termasuk rendah; b) Analisis siswa: level van Hiele siswa kelas IX F di SMPN 2 Krian terdiri dari 6 siswa level Pravisualisasi, 17 siswa level 0, dan 10 siswa level 1 sehingga dari klasifikasi level van Hiele tersebut, perangkat pembelajaran berbasis teori van Hiele dapat dikembangkan dengan berdasar pada aktivitas siswa pada level 0 sampai level 1; c) Analisis konsep: kesebangunan bangun datar; d) Analisis tugas; e) Spesifikasi tujuan pembelajaran.

Tahap selanjutnya adalah tahap perancangan. Tahap perancangan terdiri dari beberapa fase, yaitu a) Penyusunan tes: tes disusun berdasarkan tahap pendefinisian untuk mengukur peningkatan HOTS siswa dalam bentuk THB 3 soal uraian; b) Pemilihan format RPP, LKS, dan THB menggunakan komponenkomponen RPP sesuai kurikulum 2013; c) Perancangan awal: penelitian ini mengembangkan perangkat pembelajaran kesebangunan bangun datar berupa RPP, LKS, dan THB.

Tahap terakhir adalah tahap pengembangan, yaitu a) Perangkat pembelajaran divalidasi oleh validator; b) Uji pengembangan: uji coba perangkat pembelajaran terhadap kelas IX F di SMPN 2 Krian; c) Analisis hasil uji coba: menganalisis instrumen penelitian dari hasil uji coba untuk mengetahui apakah perangkat pembelajaran baik atau tidak.

(2) Hasil pengembangan perangkat pembelajaran kesebangunan bangun datar berbasis teori Van Hiele untuk meningkatkan kemampuan berpikir tingkat tinggi siswa yang valid, praktis, dan efektif sebagai berikut.

Kriteria validasi RPP, LKS, dan THB termasuk valid maka dapat dinyatakan valid;

Kriteria pengelolaan pembelajaran termasuk baik, penilaian secara umum pada lembar validasi perangkat pembelajaran dinyatakan dapat digunakan, dan persentase aktivitas siswa aktif pada pertemuan kedua dan pertemuan ketiga masing-masing sebesar 91,25\% dan 91,25\% maka dapat dinyatakan praktis; dan

Persentase respon positif siswa sebesar $71 \%$ dan N-Gain setiap siswa, yaitu $71 \%$ berkategori tinggi, $29 \%$ berkategori sedang, dan $0 \%$ berkategori rendah. N-Gain setiap kategori HOTS siswa, yaitu kategori menganalisis sebesar 0,779 berkategori tinggi, kategori mengevaluasi sebesar 0,777 berkategori tinggi, dan kategori mencipta sebesar 0,640 berkategori sedang. N-Gain secara keseluruhan dari nilai rata-rata total pretest dan rata-rata total posttest sebesar 0,728 berkategori tinggi maka dapat dinyatakan efektif.

Dari penelitian ini, peneliti menyarankan kepada guru dan peneliti lain sebagai berikut.

(1) Pembelajaran dengan mengintegrasikan teori van Hiele sebaiknya diterapkan saat kesebangunan bangun datar dilaksanakan agar pembelajaran dapat berjalan 
efektif dan memenuhi kurikulum 2013 karena mengintegrasikan HOTS.

(2) Penelitian yang sejenis ini dilakukan untuk lebih mendalam hingga tahap penyebaran dan melakukan penelitian untuk materi kesebangunan dua segitiga.

(3) Pengukuran kemampuan siswa yang sebenarnya agar ketuntasan belajar klasikal tercapai sebaiknya membuat THB yang memiliki perbandingan yang sesuai, yaitu $\mathrm{C} 1: \mathrm{C} 2: \mathrm{C} 3456=3: 5: 2$ atau $2: 5: 3$. Dengan keterangan: C1, C2, C3 adalah kategori kemampuan berpikir tingkat rendah dan C4, C5, C6 adalah kategori kemampuan berpikir tingkat tinggi.

(4) Penentuan waktu pada RPP sebaiknya dibuat dengan diskusi terlebih dahulu dengan guru mitra tentang kegiatan siswa pada waktu yang akan datang sehingga waktu yang telah dibuat tepat dengan keadaan siswa yang sebenarnya.

(5) Peneliti lain sebaiknya menyiapkan seorang untuk bisa memotret setiap dilaksanakan uji coba agar dapat menunjukkan gambaran saat uji coba berlangsung.

\section{DAFTAR PUSTAKA}

Abdussakir. 2009. "Pembelajaran geometri sesuai teori Van Hiele". Research Repository Universitas Islam Negeri Maulana Malik Ibrahim. Madrasah. Vol. 2 (1).

Kamaruddin, Rahmat, dkk. 2014. "Pengembangan Perangkat Pembelajaran Matematika Materi Geometri Berbasis Teori Belajar Van Hiele Untuk Mengembangkan Karakter Siswa Kelas VII1 SMP 2 Bulupoddo". Jurnal Matematika dan Pembelajaran. Vol. 2 (1).

Kasturi, dkk. 2015. Pengembangan perangkat pembelajaran problem posing berorientasi penerapan HOTS pada materi kesebangunan kelas IX. Jurnal Pancaran Pendidikan. Vol. 4 (1), 1132.

Kementerian Pendidikan dan Kebudayaan. 2017. Silabus Mata Pelajaran Sekolah Menengah Bawah/Madrasah Tsanawiyah (SMP/MTs). Jakarta: Pusat Kurikulum dan Perbukuan, Balitbang, Kemdikbud.

Kementrian Pendidikan dan Kebudayaan. 2019. Pusat Penilaian Pendidikan. Informasi Hasil UN SMP Tahun 2018/2019, (Online), (https://puspendik.kemdikbud.go.id/hasil-un/, diakses 9 Oktober 2019).

Kementrian Pendidikan dan Kebudayaan. 2019. Pusat Penilaian Pendidikan. Daya Serap Hasil UN SMP Tahun 2018/2019,

(Online), (https://puspendik.kemdikbud.go.id/hasil-un/, diakses 9 Oktober 2019).

Krathwohl. 2002. “A Revision of Bloom's Taxonomy: An Overview”. Theory Into Practice. Vol. 41 (4).

Masriyah, I Kurniasari, dan E L W Palupi. 2018. "Characteristics of pre-service teachers' performance in problem posing". Journal of Physics. Coference Series 1088 (1), 012115.

Masriyah. 2018. Asesmen Proses dan Hasil Belajar. UNESA: UNESA University Press.

Nurdin, Reskhi Dwi Yanti. 2016. Efektivitas Pembelajaran Icare Terintegrasi Teori Van Hiele Dalam Pembelajaran Geometri Pada Siswa Kelas X Mia9 Di Sma Negeri 1 Sungguminasa. Thesis diterbitkan. Makassar: Universitas Negeri Makassar.

Prasetyo, dkk. 2019. Pengelolaan Kurikulum (MPPKSKUR). Jakarta: Direktorat Jenderal Guru dan Tenaga Kependidikan.

Puspitasari, Dwi Indra. 2013. Pengembangan Bahan Ajar Berbasis Tahap Berpikir Van Hiele Untuk Meningkatkan Pemahaman Konsep Geometri. Tesis diterbitkan. Bandar Lampung: Universitas Lampung.

Rosnawati, R. 2013. "Kemampuan Penalaran Matematika Siswa SMP Indonesia pada TIMSS 2011”. Makalah disajikan dalam Prosiding Seminar Nasional Penelitian, Pendidikan dan Penerapan MIPA, Fakultas MIPA, Universitas Negeri Yogyakarta, Yogyakarta, 18 Mei 2013.

Siregar, Yuningsih. 2016. Pengembangan Tes Diagnostik Untuk Menganalisis Kesulitan Belajar Siswa Pada Materi Kesebangunan Ditinjau dari Taksonomi Blom di Sekolah Menengah Pertama Sederajat Medan. Tesis diterbitkan. Medan: Program Studi Pendidikan Matematika Pascasarjana Universitas Negeri Medan.

Sunardi. 2005. Pengembangan Model Pembelajaran Geometri Berbasis Teori Van Hiele. Disertasi tidak diterbitkan. Surabaya: Universitas Negeri Surabaya.

Thiagarajan, S; Semmel, D.S; \& Semmel, M.I. 1974. Instructional Development for Training Teachers of Exceptional Children: A Sourcebook. Indiana: Indiana University.

Vojkuvkova. 2012. "The Van Hiele Model of Geometric Thinking". WDS'12 Proceedings of Contributed Papers, Part I, 72-75.

Yamasari, Yuni. 2010. "Pengembangan Media Pembelajaran Matematika Berbasis ICT yang Berkualitas". Jurnal disajikan dalam Seminar Nasional Pascasarjana, ITS, Surabaya, 4 Agustus 2010. 